\title{
PATINA Network - Performance of coil coating in natural atmospheres of Ibero-America
}

\author{
B.M. Rosales*, A.R. Di Sarli ${ }^{* *}$, F. Fragata ${ }^{* * * *}$, F. Corvo ${ }^{* * * * *}$, M.S. de Villalaz ${ }^{* * * * * *}$, \\ S. Flores ${ }^{* * * * * * *}$, E. Almeida ${ }^{* * * * * * * *}$, J. Simancas ${ }^{* * * * * * * * *}$, S. Rivero ${ }^{* * * * * * * * * *}$ \\ and O.T. de Rincón ${ }^{* * * * * * * * * *}$
}

\begin{abstract}
The research work performed on 12 coil coating materials in the frame of the PATINA Network (Anticorrosive Protection in the Atmosphere) sponsored by CYYTED is discussed. It includs the task accomplished by Science and Technology institutions of Ibero-America on formulations supplied by different production Sector companies from the participating countries, between 1996 and 2000. Coil coating schemes were exposed outdoors, according to ISO 2810 standards, in 9 ambient conditions of the MICAT (IberoAmerican Test Stations Network), CYTED. The protective characteristics on the steel base metal was determined as a function of time, following ISO 4628 and ASTM D 3274 standards. Electrochemical impedance spectroscopy (EIS) was applied on various materials after 1, 2, 3 years and 42 months exposure, to evaluate the weathering effect in different atmospheric conditions.
\end{abstract}

Keywords Coil-coating. Outdoor performance. Ibero-America. Atmospheres.

\section{Red PATINA - Comportamiento de recubrimientos para banda contínua en atmósferas de Iberoamérica}

Resumen

Se discute el trabajo realizado sobre 12 diferentes recubrimientos para banda continua en el marco de la Red PATINA (Protección Anticorrosiva en la Atmósfera), patrocinada por el CYTED. Incluye las actividades llevadas a cabo por instituciones de Ciencia y Técnica de Iberoamérica, sobre distintas formulaciones provistas por empresas productoras de los países participantes, entre 1996 y 1999. Se expusieron a la intemperie, en distintas condiciones ambientales de la Red de Estaciones MICAT, CYTED, siguiendo la norma ISO 2810, recubrimientos de diferentes formulaciones. Se evaluaron las características protectoras sobre el acero de base en función de los parámetros medio-ambientales y los tiempos de exposición programados, según la normas ISO 4628, 4623 y ASTM D 3274. Se aplicaron dos esquemas de protección orgánicos sobre las muestras de acero, otros cuatro sobre muestras de acero previamente protegido con $\mathrm{Zn}$ y otros seis sobre acero galvanizado (2) y recubierto con galvalume (4), con y sin incisión en cada esquema hasta llegar el acero. Se discuten los resultados obtenidos al cabo de 1, 2, 3 años y 42 meses en función de la agresividad de cada sitio de ensayo. Se aplicó espectroscopía de impedancia electroquímica (EIE) al cabo de diferentes períodos de exposición para evaluar la incidencia del deterioro de cada recubrimiento sobre la respuesta global de los esquemas, en varias de las condiciones de ensayo.

Palabras clave Recubrimiento para banda contínua. Comportamiento a la intemperie. Iberoamérica. Atmósferas.

\footnotetext{
(*) CITEFA-DEICOR. Zufriategui 4380, (1603) Villa Martelli, Argentina.

$(* *) \quad$ CIDEPINT, CIC-CONICET. 52 e/121 y 122, (1900) La Plata, Argentina.

$(* * *) \quad$ CEPEL. Il ha da Cidade Universitaria. Río de Janeiro (Brazil).

$\left({ }^{* * *}\right) \quad$ Centro Nacional de Investigaciones Científicas. (Cuba).

$\left(^{* * * * *} \quad\right.$ Universidad Tecnológica de Panamá (Panamá).

$(* * * * *) \quad$ Pontificia Universidad Católica del Perú. (Perú).

$(* * * * * *)$ Instituto Nacional de Engenharia e Tecnología Industrial (INETI), Estrada do Paço do Lumiar, 1649-038 Lisboa (Portugal).

(*******) Centro Nacional de Investigaciones Metalúrgicas (CENIM).

$(* * * * * * * *) \quad$ Universidad de la República. Montevideo (Uruguay).

(*********) Universidad del Zulia, Facultad de Ingeniería (Venezuela).
}

Rev. Metal. Madrid Vol. Extr. (2003) 201-205 
PATINA Network - Performance of coil coating in natural atmospheres of Ibero-America

B.M. Rosales, A.R. Di Sarli, F. Fragata, F. Corvo, M.S. de Villalaz, S. Flores, E. Almeida, J. Simancas, S. Rivero and

O.T. DE RINCÓN

\section{INTRODUCTION}

Coil coating or pre-painting steel, is a novel and one of the most advanced steel anticorrosive protection technologies, developed to promote steel utilisation in the most varied environmental conditions. It consists of a metallic and then an organic coating, both of low thickness, applied in continuous on thin steel coil. Steel metallic substratum is generaly coated with zinc or a $\mathrm{Zn}$ alloy, as galvalume (with $55 \% \mathrm{Al}$ and $1.5 \% \mathrm{Si}$ ), which provides extra protection and great performance improvement against atmospheric corrosion.

Electrochemical impedance spectroscopy (EIS) was applied after various exposure times to determine mechanistic parameters affecting the protectiveness of the distinct schemas, such as the barrier effect of the organic films, the influence of the 2 different $\mathrm{Zn}$ base coatings, base and finishing paints, the underlying corrosion of sustrata, etc.

A good description of the experimental impedance diagram can be obtained from the analysis of the transference function using nonlinear fitting routines, like those developed by Boukamp ${ }^{[1]}$.

This research work was carried out by Group 6: "Coil Coating" of PATINA Network, in the XV Sub-program "Environmental Impact on Materials", CYTED, for the 1996-2000 period.

\section{EXPERIMENTAL}

Results after the final 42 month's testing, of 12 formulations described in table I, in 9 of the 72 test sites of the MICAT Latin American Network, characterised in table II, are discussed.

Atmospheric exposure evaluation of defects in the organic coatings, with and without incisions, was performed every 6 months, according to ISO 4628/1 to $6^{[3]}$ and ASTM D3274 ${ }^{[4]}$ standards.

EIS was yearly applied on A1 to A6 weathered panels. The electrochemical experiments were carried out at $20 \pm 2{ }^{\circ} \mathrm{C}$ in a Faraday cage, after 1-hour immersion in $\mathrm{NaCl}$ solution $3.5 \% \mathrm{w} / \mathrm{v}, \mathrm{pH}$ 8.2, as electrolyte. A Solartron 1255 frequency

Table I. Characteristics of the tested materials

Tabla I. Características de los materiales ensayados

\begin{tabular}{|c|c|c|c|c|c|c|c|c|c|c|}
\hline \multirow{3}{*}{ Code } & \multirow{3}{*}{$\begin{array}{l}\text { Metallic } \\
\text { coating }\end{array}$} & \multirow{3}{*}{$\begin{array}{l}\text { Thickn. } \\
(\mu \mathrm{m})\end{array}$} & \multicolumn{8}{|c|}{ Paint } \\
\hline & & & \multicolumn{3}{|c|}{ Base } & \multicolumn{3}{|c|}{ Finishing } & \multirow{2}{*}{\multicolumn{2}{|c|}{$\overline{E(\mu \mathrm{m})} \frac{\text { Total thick. }}{\mathrm{E}(\mu \mathrm{m})}$}} \\
\hline & & & Vehicle & Pigm. $\left(^{* *}\right)$ & $E(\mu \mathrm{m})$ & Vehicle & Pigment & Colour & & \\
\hline A1 & Galvalume & 20 & Epoxy & $\mathrm{Ti}, \mathrm{Cr}, \mathrm{Co}, \mathrm{Al}$ & 4 & PVDF & $\mathrm{Al}, \mathrm{Ti}, \mathrm{Fe}, \mathrm{Si}$ & Light Blue & 20 & 44 \\
\hline $\mathrm{A} 2$ & $\mathrm{Zn}$ & 20 & Epoxy & $\mathrm{Fe}, \mathrm{Cr}, \mathrm{Zn}, \mathrm{Ti}$ & 6 & PVDF & $\mathrm{Fe}, \mathrm{Zn}, \mathrm{Si}$ & Blue & 17 & 43 \\
\hline A3 & $\mathrm{Zn}$ & 20 & Epoxy Acrilic & $\mathrm{Si}, \mathrm{Fe}, \mathrm{Ti}$ & 6 & Poly. Silic. & $\mathrm{Fe}, \mathrm{Si}, \mathrm{Pb}$ & Red & 17 & 43 \\
\hline A4 & Galvalume & 20 & Polyester & $\mathrm{Fe}, \mathrm{Si}, \mathrm{Ti}$ & 5 & Poly. Silic. & $\mathrm{Fe}, \mathrm{Si}, \mathrm{Al}, \mathrm{Ti}$ & Light Blue & 17 & 42 \\
\hline A5 & Galvalume & 20 & Epoxy & $\mathrm{Fe}, \mathrm{Si}, \mathrm{Ti}$ & 4 & PVDF & $\mathrm{Al}, \mathrm{Si}, \mathrm{Ti}$ & Red & 19 & 43 \\
\hline A6 & Galvalume & 20 & Polyester & $\mathrm{Ti}, \mathrm{Si}, \mathrm{Al}$ & 5 & Polyester & $\mathrm{Ti}, \mathrm{Si}, \mathrm{Al}$ & White & 18 & 43 \\
\hline $\mathrm{CH} 1$ & - & - & Epoxy & $\mathrm{Fe}, \mathrm{Si}$ & 15 & Polyester & $\mathrm{Fi}, \mathrm{Fe}, \mathrm{Al}, \mathrm{Si}$ & Beige & 15 & 30 \\
\hline $\mathrm{CH} 2$ & - & - & Epoxy & $\mathrm{Fe}, \mathrm{Si}$ & 15 & Polyester & $\mathrm{Fe}, \mathrm{Si}$ & Brown & 15 & 30 \\
\hline E1 & $\mathrm{Zn}$ & 20 & Polyester & $\mathrm{Ti}, \mathrm{Al}, \mathrm{Si}$ & 20 & Polyester & $\mathrm{Ti}, \mathrm{Al}, \mathrm{Si}$ & White & 15 & 55 \\
\hline E2 & $\mathrm{Zn}$ & 25 & Polyester & $\mathrm{Ti}, \mathrm{Cr}, \mathrm{Si}, \mathrm{Al}$ & 20 & Poly. Silic. & $\mathrm{Fe}, \mathrm{Si}, \mathrm{Ti}, \mathrm{Ca}$ & Red & 10 & 55 \\
\hline E3 & $\mathrm{Zn}$ & 20 & Epoxy Aminopl. & $\mathrm{Fe}, \mathrm{Ti}, \mathrm{Si}$ & 20 & PVDF & $\mathrm{Fe}, \mathrm{Al}, \mathrm{Si}$ & Green & 16 & 56 \\
\hline$(*) E 4$ & $\mathrm{Zn}$ & 25 & - & - & - & Alcid. Melam. & Ti, Si, Al & White & 25 & 50 \\
\hline
\end{tabular}

(*) NILU (Norway)

${ }^{(* *)}$ Elements detected through EDX, in decreasing order of relative abundance. 
PATINA Network - Performance of coil coating in natural atmospheres of Ibero-America B.M. Rosales, A.R. Di Sarli, F. Fragata, F. Corvo, M.S. de Villalaz, S. Flores, E. Almeida, J. Simancas, S. Rivero and

O.T. DE RINCÓN

Table II. Ambient characteristics and corrosivity of the 9 test atmospheres

Tabla II. Características ambientales y de corrosividad de las 9 estaciones de ensayo

\begin{tabular}{|c|c|c|c|c|c|c|c|c|c|c|c|c|}
\hline \multirow{3}{*}{ Country } & \multirow{3}{*}{ Station } & \multirow{3}{*}{ Atmos. } & \multirow{3}{*}{$\begin{array}{c}\mathrm{T} \\
{ }^{\circ} \mathrm{C}\end{array}$} & \multirow{3}{*}{$\begin{array}{c}\mathrm{RH} \\
\%\end{array}$} & \multirow{3}{*}{$\begin{array}{c}\text { TOW } \\
\%\end{array}$} & \multirow{3}{*}{$\begin{array}{l}\text { Rain } \\
\mathrm{mm} / \mathrm{y}\end{array}$} & \multirow{3}{*}{$\begin{array}{c}{\left[\mathrm{SO}_{2}\right]} \\
\mathrm{mg} / \mathrm{m}^{2} \mathrm{~d}\end{array}$} & \multicolumn{4}{|c|}{ Corrosion Rate ( $1^{\text {st }}$ year $)$} & \multirow{3}{*}{$\begin{array}{c}\text { Sun Hours } \\
h / y\end{array}$} \\
\hline & & & & & & & & {$\left[\mathrm{Cl}^{-}\right]$} & $\mathrm{Fe}$ & $\mathrm{Zn}$ & Sun Rad. & \\
\hline & & & & & & & & $\mathrm{mg} / \mathrm{m}^{2} \mathrm{~d}$ & \multicolumn{2}{|c|}{$\mu \mathrm{m} / \mathrm{y}$} & $\mathrm{KJ} / \mathrm{cm}^{2} \mathrm{y}$ & \\
\hline Argentina & Jubany & Marine-Polar & $r-2.7$ & 84 & 29.3 & 278 & Ins. & ${ }^{*} 16.50$ & 37.3 & 1.89 & $* * 290$ & $* * 434$ \\
\hline Brasil & Cubatao & Indust. & 22.7 & 74 & 57.9 & 988 & 54.53 & 8.14 & 43.7 & 1.98 & 387 & 1980 \\
\hline Cuba & Viriato & Marine & 25.1 & 79 & 57.1 & 1413 & 19.00 & 368.30 & 445.8 & 11.1 & 530 & - \\
\hline España & El Pardo & Rural & 15.0 & 55 & 36.6 & 420 & 6.40 & 3.9 & 12.6 & 0.27 & 604 & 2700 \\
\hline Panamá & Panamá & Urban & 26.9 & 71 & 57.2 & 1557 & 21.71 & 9.76 & 27.6 & 0.6 & 413 & 1960 \\
\hline Perú & Lima & Urban & 23.1 & 80 & 59.6 & 16 & 14.30 & 77.86 & 134.2 & 9.28 & 499 & 1376 \\
\hline Portugal & Lumiar & Urban & 153 & 73 & 13.5 & 485 & 22.60 & 19.60 & 33 & 0.61 & 650 & 2802 \\
\hline Uruguay & $\begin{array}{l}\text { Punta } \\
\text { del Este }\end{array}$ & Marine & 16.5 & 78 & 53.8 & 823 & 3.95 & 143.50 & 49 & 1.89 & 568 & 2348 \\
\hline Venezuela & La Voz & Marine-Vulc. & 28.0 & 92 & 48.3 & 398 & 9.50 & 567.70 & 922 & 26.5 & 490 & 3073 \\
\hline
\end{tabular}

Data from the book "Mapas de Iberoamérica de Corrosividad Atmosférica"[2].

$\left.{ }^{*}\right)$ Determined from $\mathrm{Cl}^{-}$content in water monthy collected in pluvionivograph of Jubany Base $(1993-95,98)$.

$\left.{ }^{* *}\right)$ Data determined (1996-98).

response analyser coupled to a Solartron electrochemical interphase 1286 and a PC were used. Impedance data was collected starting at 1 $\mathrm{MHz}$ up to $1 \mathrm{mHz}$ and interpreted on the basis of equivalent electrical circuits, using a suitable fitting procedure.

\section{RESULTS}

- Outdoor exposure. Rain, dew, high relative humidity and important temperature decrease cause the liquid water contact with the test pannels, designed as "time of wetness" (TOW). The sun radiation synergises the TOW's effects, enhancing deterioration of components pigments and polymers of the coating. When water and the environmental contaminants reach the underlying metal, the corrosion phenomenon is added to the coating damage, accelerating the irreversible damage.

Once steel corrosion starts on samples in which the organic coating was applied, rapidly growing blisters appear and high deterioration rate occurs at the incision and borders. Conversely, materials in which steel was coated with $\mathrm{Zn}$ or galvalume, only evidence slow white corrosion, even in the most aggressive environments. When the $\mathrm{Zn}$ coating locally dissappears its cathodic protection stops, and orange corrosion points appear due to the base steel attack at the incision and borders. Away from the borders, corrosion and blistering are slower than at the incision because they occur through paint films.

- EIS. When there is no electrolyte solution within the metal/organic coating interface, no electrochemical double layer formation nor faradaic reactions occur, being the only information obtained from impedance data that related with the dielectric properties of the organic coating. A first interpretation of the complex plane plot may be described by a transfer function corresponding to an equivalent circuit built up from a series combination of the electrolyte resistance $\left(R_{s}\right)$ with the paint film dielectric capacitance $\left(C_{1}\right)$. As the exposure time goes on, the amount of permeating water, oxygen and ions increase the coating conductivity, becoming measurable the resistance $\left(R_{1}\right)$ associated to the dielectric capacitance $\mathrm{C}_{1}$. In such conditions, the impedance diagram and equivalent circuit, together with information about the membrane ionic resistance $\left(R_{1}\right.$, which describes paths of lower resistance short-circuiting the organic coating), and the dielectric capacitance $\left(\mathrm{C}_{1}\right.$, whose value is associated with the water uptake) can be obtained. Once the permeating 
PATINA Network - Performance of coil coating in natural atmospheres of Ibero-America

B.M. Rosales, A.R. Di Sarli, F. Fragata, F. Corvo, M.S. de Villalaz, S. Flores, E. Almeida, J. Simancas, S. Rivero and

O.T. DE RINCÓN

species reach the metallic substrate corrosion processes may initiate, causing the emergence of the electrochemical double layer $\left(\mathrm{C}_{2}\right)$ and the charge transfer resistance $\left(\mathrm{R}_{2}\right)$ proper of a faradaic process, related as $1 / R_{2}$ with the corrosion rate. In this case, the impedance response and the corresponding equivalent circuit modelling the coated metal $/ 3.5 \% \mathrm{NaCl}$ solution are those exhibited in figure $1^{[5]}$.

Ionic resistance $\left(R_{1}\right)$ values ranged from $10^{3} \Omega \mathrm{cm}^{2}$ up to greater than $10^{8} \Omega \mathrm{cm}^{2}$. These resistance values are inversely related to the average cross-section of the conductive pathways between the metal and the electrolyte. Therefore, they suggest that penetration of the paint by the electrolyte solution after 12 or 24 months exposure to different atmospheric media was highly dependent on both the painting system formulation and the aggressiveness conditions. Accordingly, the lower values obtained coincided with large rust spots on the specimens, confirming their poor barrier and anticorrosive properties under the experimental conditions.

On the other hand, the high anticorrosive protection found in samples where $R_{1}>10^{8}$ $\Omega \mathrm{cm}^{2}$ was attributed to the great influence of the mechanism described by the barrier and insulating effect model (i.e., the paint capacity for delaying the diffusion of aggressive species up to the metal paint interface), added to an effective anticorrosive action of the pigments incorporated to the primers. In agreement with this mechanism, it was assumed that the metal surface was effectively kept isolated from the 3.5 $\% \mathrm{NaCl}$ solution during EIS measurements.

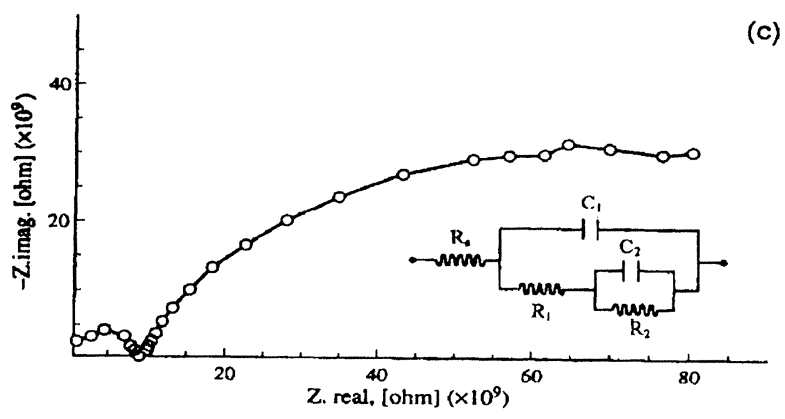

Figure 1. Complex plane plot for a combination $R_{s}$ with two time constants $\left(R_{1} C_{1}\right)$ and $\left(R_{2} C_{2}\right)$.

Figura 1. Gráfico del plano complejo para una combinación de $R_{5}$ con dos constantes de tiempo $\left(R_{l} C_{l}\right)$ y $\left(R_{2} C_{2}\right)$.
Results related with the charge transfer resistance $\left(R_{2}\right)$ of the different samples show that the values of this parameter vary between $10^{7}-10^{2} \Omega \mathrm{cm}^{2}$. The lower denote a progress of the active (corroding) metal surface beneath the paint film due to an increase of both the pore density and the metal electrolyte contact area, while the higher indicates that there is an effective insulating effect provided by the painting system. Correspondingly, the double layer capacitance $\left(\mathrm{C}_{2}\right)$ can provide information about the extent of the underfilm corroding area as a consequence of the protective coating degradation ${ }^{[6]}$. Blistering of organic coatings applied on steel is a very common phenomenon under service conditions. According to Kreese $^{[7]}$, osmosis plays an important role in blistering due to the fact that unidirectional transport allows the accumulation of water between the coating and the substrate.

\subsection{Ionic resistance vs. exposure time for $\mathrm{A} 1$ to A6 materials}

This EIS results showed a clear decrease of the organic coating resistance with time for samples A1 to A6, after the first yearly period. On the contrary, coating resistance increased after the second year in the most aggressive of the testing atmospheres $(\mathrm{La}$ $\mathrm{Voz}$ ) for samples A1, A3 and A6 when corrosion of the metallic sustratum produced $\mathrm{Zn}$ corrosion products, causing a blocking effect on paints pores. For other schemas and also for the same samples but in milder marine test sites, decresing values were determined for longer periods.

In the 3 marine test stations, with very different yearly mean $\mathrm{T}$, sun radiation and hours, $\mathrm{SO}_{2}$ and $\left[\mathrm{Cl}^{-}\right]$, etc. the most sensitive failure for all the formulations in the exposed atmospheric conditios was blistering at the incision. The changes with time in the magnitude of this failure for A1, A2 and A3 showed that the most significant environmental parameter was the TOW. In spite of the great difference among those marine atmospheres, other data than sun radiation and $\left[\mathrm{Cl}^{-}\right]$did not show a significant correlation with the magnitude of the damage variation. Comparing the changes with the time of the paint schema resistance for the 3 materials it could be concluded that the best one was A2, the following was A3 and finally $\mathrm{A} 1$. This result was also observed in all the continental marine atmospheres. In the antarctic marine atmosphere of Jubany Base 
practically no variations were detected with time in paint resistance for all materials, up to the final test period. In good agreement with the absence of color change and the lowest gloss decrease, as compared with the rest of the atmospheres, it could be attributed to the low accumulated sun radiation and sun hours during each test period.

Materials A4 and A5 showed very little change in the organic coating resistance after the first year exposure in $\mathrm{La} \mathrm{Voz}$, appearing at the end of the second year a sudden change in A5, that destroyed completely the paint film in most atmospheres since that time.

In marine atmospheres best behaviour was observed for A4 schema and worst for A5. In urban ambients best behaviour was found for material $\mathrm{A} 2$ and the worst for A6.

\section{CONCLUSIONS}

- The best performances of the tested coil coating materials were observed after exposures in Test Stations of lowest aggressiveness, this being mainly determined by the TOW and by their pollutant content.

- Industrial solid pollutants at the Cubatao Station had a strong negative aesthetic effect on all formulations, determined by the hardness of particles emitted by chimneys of the steel mill works, where the Test Station is located. This effect was more evident in samples which organic film surface hardness was lowest. This solid pollutant effect did not allow to appreciate the expected result of the high $\mathrm{SO}_{2}$ concentration on the steel protectiveness.

- Best behaviour before corrosion after 42 month's test was observed when metallic coating was deposited on steel. Better results were obtained for galvalume than for $\mathrm{Zn}$.

- The $\mathrm{R}_{1}, \mathrm{C}_{1}, \mathrm{R}_{2}$ and $\mathrm{C}_{2}$ values obtained from EIS kept good correlation with the characteristics observed during visual inspection.

- Among the metal coated samples designed A the best performance was shown by formulation A4 and the worst was A5.
- Among the metal coated samples designed E the best performance was shown by formulation A3, followed by E2 and the worst behaviour was observed for A4.

- The protective schema thickness greatly affects the behavior. The great dispersion determined with different samples introduced uncertainty in results.

- Among the overall set of formulations the main causes of the improved resitance to most aggressive atmospheres:were the metallization with galvalume vs.to $\mathrm{Zn}$ and the total paint coating thickness. Better protection could be attributed to the PVDF as compared to polyester finishing coatings.

\section{Acknowledgements}

The authors gratefully acknowledge to CYTED for financing the National Coordinators Meetings and to CIC and CONICET for their financial support of this research work. They also recognise Bettina Marchisio's assistance during the preparation of this paper.

\section{REFERENCES}

[1] B. A. Boukamp, Report CT88/265/128, CT89/214/128, University of Twente, Netherlands, 1989.

[2] Corrosión y Protección de Metales en las Atmósferas de Iberoamérica. Parte 1- Mapas de Iberoamérica de Corrosividad Atmosférica, Ed. M. Morcillo, E. Almeida, B. Rosales, J. Uruchurtu y M. Marrocos, España, 1998.

[3] ASTM D 3274. Evaluating degree of surface desfigurement of paint films by fungol growth or soil and dirt accumulation.

[4] ISO 4628, Paints and varnishes-Notes for guidance on conduct of natural weathering tests. Part 1 to Part 6: Designation of degree of chalking.

[5] O. Ferraz, E. Cavalcanti and A.R. Di Sarli, Prog. Org. Coat. 37 (1995) 1.267.

[6] L.M. Callow and J.D. Scantlebury, J. Oil Col. Chem. Assoc. 64 (1981) 119.

[7] P. KREESE, Farbe + Lack 72 (1966) 1.179. 